\title{
STRATEGI PENINGKATAN KINERJA BADAN AMIL ZAKAT DAERAH (BAZDA) KABUPATEN NGANJUK (Studi A nalisis dengan M etode Balanced Scorecard)
}

\author{
M ukhamad Zakariya \\ Institut A gama Islam Diponegoro N ganjuk \\ e-mail: muhammad_zakariyah@yahoo.co.id
}

\begin{abstract}
To optimize the role of BAZDA, it requires good fund management strategy so as to create public confidence in disbursing the fund to Bazda rather than giving it directly to mustahik. Directly channeling is closer to the consumptive use that it somewhat obscures productive purposes. Author feel interested in doing research related to performance improvement strategy of BAZDA N ganjuk residence to the management of zakat, infaq, and sadaqah with Balanced Scorecard method. This study titled "Strategy for Performance Improvement of BAZDA Nganjuk Residence (Study A nalysis of the Balanced Scorecard method) ". Type of research used in this paper is qualitative, that is research procedure that produces descriptive data in the form of written or spoken words' people and behaviors that can be observed. The data used in this study can be divided into two. First, the primary data, that is in the form of interviews with a N ganjuk BAZ board, local government and muzakki. Second, Secondary Data, it is obtained through the financial statements of BAZDA $\mathrm{N}$ ganjuk and also from the literature books that support theory of research. The result of study shows; (a) on the basis of the financial perspective, there are still some potential areas of real that can not be absorbed optimally; (b) on the basis of business process perspective, realization of consumptive utilization of zakat is greater than the productive empowerment of zakat; (c) on the basis of customer perspective, when the process of zakat socialization is associated with the result of fund raising, and there are still some potency of zakat that is optimally untapped, it still requires an effort to socialize it more proactive; (d) on the basis of growth and learning, for progress institution of BAZDA N ganjuk, it requires reference sources, both internal and external agencies. Internal agency may be the agency's each period of performance report, while the external agency is from muzakki and mustahik.
\end{abstract}

Keywords Strategy, performance of B A ZDA, balanced scorecard method

\section{Pendahuluan}

Zakat adalah merupakan tatanan agama untuk mewujudkan keadilan sosial bagi seluruh umat. Hukum zakat adalah wajib bagi seorang muslim yang mampu dan yang sudah memenuhi ketentuan berzakat. M embayar zakat adalah merupakan wujud rasa syukur kepada 
Allah SWT atas limpahan karunia yang telah diberikan. Dengan berzakat, manusia menghilangkan sifat kikir dan menumbuhkan jiwa sosial yang tinggi. Selain itu, yang lebih utama adalah wujud pembersihan jiwa manusia dan harta benda yang dimiliki dari hak-hak orang lain. Perintah untuk mengambil zakat dari setiap muslim yang sudah memenuhi sayarat berzakat telah dijelaskan dalam al-Quran :

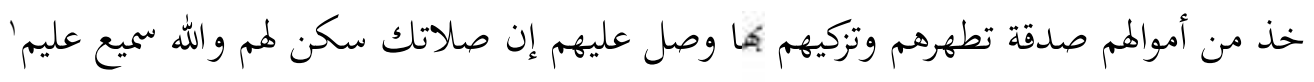

"A mbillah zakat dari sebagian harta mereka, dengan zakat itu kamu membersihkan dan mensucikan mereka dan mendoalah untuk mereka. Sesungguhnya doa kamu itu (menjadi) ketenteraman jiwa bagi mereka. dan Allah $\mathrm{M}$ aha mendengar lagi Maha M engetahui"

Dari ayat di atas bahwa A llah memberikan perintah kepada Rasul-Nya dan semua umat yang memimpin setelah beliau untuk mengambil zakat dari orang kaya yang sudah jelas ketentuannya, karena zakat membersihkan diri mereka dari sifat bakhil, tamak dan mengangkat derajat menjadi orang-orang yang ikhlas. Pembayaran zakat bukan hanya sekadar pemberian bantuan sosial dari yang kaya kepada orang yang miskin atau kepada mustahik lainnya, melainkan hak tuhan dan hak orang-orang fakir, miskin dan para mustahik zakat yang wajib diberikan oleh seorang muzakki kepada mereka.

Kewajiban zakat memiliki berbagai fungsi strategis dalam sendi-sendi Islam. Zakat tidak hanya sebagai wujud ibadah kepada Allah SWT atau kewajiban moralitas bagi umat Islam, tetapi berfungsi pula sebagai alternatif instrumen kebijakan fiskal untuk mewujudkan pemerataan pendapatan di antara umat Islam. Zakat diharapkan mampu mengangkat derajat fakir miskin dan membantu keluar dari kesulitan hidup. M embantu pemecahan masalah yang dihadapi oleh para mustahik, menghilangkan sifat kikir dan mempererat tali persaudaraan sesama umat Islam.

Di era globalisasi, tingkat persaingan semakin ketat, setiap perusahaan semakin dihadapkan pada kelangkaan dalam pengadaan, penguasaan, dan pemilikan sumber-sumber daya sehingga tidak ada alasan untuk membenarkan terjadinya inefisiensi. ${ }^{2}$ Penilaian atau pengukuran kinerja adalah penentuan secara periodik efektivitas operasional suatu organisasi, bagian organisasi, dan personelnya, berdasarkan sasaran, standar dan kriteria yang telah ditetapkan sebelumnya. ${ }^{3}$ Pengukuran kinerja merupakan salah satu faktor yang sangat penting bagi perusahaan karena pengukuran kinerja merupakan usaha memetakan strategi ke dalam tindakan pencapaian target tertentu. Sistem pengukuran kinerja dapat dijadikan sebagai alat pengendalian organisasi karena pengukuran kinerja diperkuat dengan menetapkan reward dan punishment system. ${ }^{4}$ Pengukuran kinerja perusahaan dapat diukur dengan ukuran keuangan dan bukan keuangan.

\footnotetext{
${ }^{1}$ Q.S. at-Taubah: 103

${ }^{2}$ Sondang P. Siagian, Audit Manajemen (Jakarta: Bumi Aksara, 1999), 20

3 Mulyadi, Balanced Scorecard: Alat Manajemen Kontemporer untuk Pelipatgandaan Kinerja Keuangan Perusahaan (Jakarta: Salemba Empat, 2001), 353

${ }^{4}$ Ihyaul M.D. Ulum, Audit Sektor Publik Suatu Pengantar (Jakarta: Bumi Aksara, 2006), 46
} 
Salah satu alat untuk mengukur kinerja adalah dengan menggunakan metode Balanced Scorecard (BSC). Balanced scorecard adalah suatu kerangka kerja untuk mengintegrasikan berbagai ukuran yang diturunkan dari strategi perusahaan yaitu ukuran kinerja finansial masa Ialu dan memperkenalkan pendorong kinerja finansial masa depan, yang meliputi perspektif pelanggan, proses bisnis internal, dan pembelajaran serta pertumbuhan, diturunkan dari proses penerjemahan strategi perusahaan yang dilaksanakan secara eksplisit dan ketat ke dalam berbagai tujuan dan ukuran yang nyata. Walaupun demikian, balanced scorecard bukan merupakan sistem pengukuran semata. Berbagai perusahaan yang inovatif menggunakan scorecard sebagai kerangka kerja proses manajemen perusahaan. ${ }^{5}$

Pada awalnya konsep balanced scorecard hanya digunakan sebagai alat pengukuran kinerja pada organisasi bisnis, namun saat ini Balanced Scorecard bukan hanya digunakan oleh organisasi bisnis tetapi juga oleh organisasi publik. B alanced scorecard dapat membantu organisasi publik dalam mengontrol keuangan dan mengukur kinerja organisasi. ${ }^{6}$ Organisasi publik adalah organisasi yang didirikan dengan tujuan memberikan pelayanan kepada masyarakat. Hal ini menyebabkan organisasi publik diukur keberhasilannya melalui efektivitas dan efisiensi dalam memberikan pelayanan kepada masyarakat. Untuk itu organisasi publik harus menetapkan indikator-indikator dan target pengukuran kinerja yang berorientasi kepada masyarakat. Pengukuran kinerja pada organisasi publik dapat meningkatkan pertanggungjawaban dan memperbaiki proses pengambilan keputusan. ${ }^{7}$

Untuk mengoptimalkan peran BAZDA, diperlukan strategi pengelolaan dana yang baik sehingga mampu menciptakan kepercayaan masyarakat dalam menyalurkan dananya pada BAZDA daripada menyalurkannya langsung pada mustahik. Penyaluran secara langsung tersebut lebih dekat pada pemanfaatan konsumtif sehingga agak mengaburkan tujuan produktif. ${ }^{8}$

B erdasarkan latar belakang di atas, penulis merasa tertarik untuk melakukan penelitian terkait strategi peningkatan kinerja BAZDA Kabupaten Nganjuk terhadap pengelolaan zakat, infaq dan shadaqah jika ditelaah menggunakan metode balanced scorecard.

\section{Kajian Kepustakaan}

Strategi adalah proses untuk menentukan arah yang harus dituju oleh perusahaan agar misinya tercapai dan sebagai daya dorong yang akan membantu perusahaan dalam menentukan produk, jasa, dan pasarnya di masa depan. Strategi juga merupakan pola tindakan utama yang dipilih untuk mewujudkan visi organisasi melalui misi. Strategi dirumuskan untuk menggalang berbagai sumber daya organisasi dan mengarahkannya ke pencapaian visi organisasi. Dalam lingkungan bisnis yang kompetitif, strategi memainkan peran penting dan menentukan dalam mempertahankan kelangsungan hidup dan

\footnotetext{
${ }^{5}$ Robert S. Kaplan, dan David P. Norton, Balanced Scorecard: Menerapkan Strategi Menjadi Aksi (Jakarta: Erlangga, 2000), 16-17

${ }^{6}$ Sven Modell, "Performance Measurement Myths in Public Sector", dalam http://ssrn.com/abstract= 513564 (12 Februari 2015)

${ }^{7}$ Cristopher D. Ittner dan David F. Larcker, "Innovations in Performance Measurement: Trends and Research Inplications", dalam http://ssrn.com/abstract=513564 (12 Februari 2015)

${ }^{8}$ Mursydi, Akuntansi Zakat Kontemporer (Bandung: Remaja Rosdakarya, 2006), 141
} 
pertumbuhan perusahaan. Oleh karena manajemen strategik merupakan proses yang berkelanjutan, sekali strategi yang telah dipilih diimplementasikan, seringkali diperlukan modifikasi atas strategi tersebut, disesuaikan dengan perubahan lingkungan dan kondisi organisasi. ${ }^{9}$

Perumusan strategi dan penerjemahan strategi ke dalam langkah-langkah operasional dipenuhi dengan rangkaian pengambilan keputusan strategis. Suatu keputusan dikatakan sebagai keputusan strategis jika memenuhi syarat. Pertama, keputusan tersebut mencakup beberapa bagian organisasi atau keseluruhan komponen organisasi. Kedua, keputusan tersebut memerlukan pemerolehan dan pengalokasian sumber daya yang cukup besar (baik sumber daya manusia, keuangan, informasi dan fisik). K etiga, keputusan tersebut berdampak jangka panjang ke masa depan.

Pengertian kinerja telah dirumuskan oleh beberapa ahli manajemen antara lain. ${ }^{10}$ Stoner menyatakan bahwa kinerja adalah fungsi dari motivasi, kecakapan dan persepsi peranan. Sedangkan Prawiro Suntoro mengemukakan bahwa kinerja adalah hasil kerja yang dapat dicapai seseorang atau sekelompok orang dalam suatu organisasi dalam rangka mencapai tujuan organisasi dalam periode waktu tertentu.

Berdasarkan hal-hal di atas, dapat disimpulkan bahwa kinerja merupakan hasil-hasil fungsi pekerjaan atau kegiatan seseorang atau kelompok dalam suatu organisasi yang dipengaruhi oleh berbagai faktor untuk mencapai tujuan organisasi dalam periode waktu.

Balanced scorecard adalah salah satu alat pengukuran kinerja yang menekankan pada keseimbangan antara ukuran-ukuran strategis yang berlainan satu sama lain dalam usaha untuk mencapai keselarasan tujuan sehingga mendorong karyawan bertindak demi kepentingan terbaik perusahaan. ${ }^{11}$ Balanced scorecard terdiri dari dua kata, yaitu kartu skor (scorecard) dan berimbang (balanced). Pada tahap awal eksperimennya, balanced scorecard merupakan kartu skor yang digunakan untuk mencatat skor hasil kinerja eksekutif. M elalui kartu skor, skor yang hendak diwujudkan eksekutif di masa depan dibandingkan dengan hasil kinerja sesungguhnya. Hasil perbandingan tersebut digunakan untuk melakukan evaluasi atas kinerja eksekutif. K ata berimbang dimaksudkan untuk menunjukkan bahwa kinerja eksekutif diukur secara berimbang dari dua perspektif yaitu keuangan dan bukan keuangan, jangka pendek dan jangka panjang, internal dan eksternal. ${ }^{12}$ Dalam teori penilaian kinerja balanced scorecard adalah pengukuran yang menggabungkan antara kinerja keuangan dan bukan keuangan. A da empat perspektif kinerja bisnis yang diukur menurut balanced scorecard.

Pertama, perspektif pembelajaran dan pertumbuhan. Perspektif ini merupakan dasar bagi perspektif lainnya dalam Balanced Scorecard. Proses ini mengidentifikasi infrastruktur

\footnotetext{
${ }^{9}$ Mulyadi, Balanced Scorecard : Alat Manajemen Kontemporer untuk Pelipatgandaan Kinerja Keuangan Perusahaan (Jakarta: Salemba Empat, 2001), 72

${ }^{10}$ Moh. Pabundu Tika, Budaya organisasi dan Peningkatan Kinerja Perusahaan (Jakarta: Sinar Grafika Offset, 2006), 121

${ }^{11}$ Mathius Tandiontong dan Erna Rizky Yoland, "Penerapan Balanced Scorecard Sebagai Alat Pengukuran Kinerja Yang Memadai: Sebuah Studi Pada Perusahaan Bio Tech Sarana di Bandung", dalam Jurnal Ilmiah Akuntansi, (Mei-Agustus 2011), 5

${ }^{12}$ Mulyadi, Sistem Manajemen Strategik Berbasis Balanced Scorecard (Yogyakarta : UPP AMP YKPN, 2005), 1
} 
yang harus dibangun perusahaan untuk meningkatkan pertumbuhan dan kinerja jangka panjang. Proses pembelajaran dan pertumbuhan ini bersumber dari faktor sumber daya manusia, sistem, dan prosedur organisasi. Kedua, perspektif proses bisnis internal. Balanced scorecard dalam perspektif ini memungkinkan manajer untuk mengetahui seberapa baik bisnis mereka berjalan dan apakah produk atau jasa mereka sesuai dengan spesifikasi pelanggan. Ketiga, perspektif pelanggan. Perspektif ini mengukur sejauh mana organisasi dapat memuaskan pelanggan. Dalam perspektif pelanggan, manajer mengidentifikasi segmen pelanggan dan pasar di mana perusahaan akan berkompetisi serta ukuran kinerja yang akan digunakan pada segmen tersebut. ${ }^{13} \mathrm{~K}$ eempat, perspektif keuangan. Dalam hal ini, Balanced scorecard tetap menggunakan ukuran keuangan karena ukuran keuangan sangat penting dalam memberikan ringkasan konsekuensi tindakan ekonomis yang sudah diambil. Ukuran kinerja keuangan memberikan petunjuk apakah strategi perusahaan, implementasi dan pelaksanaannya memberikan kontribusi atau tidak kepada peningkatan laba perusahaan.

\section{Metodologi Penelitian}

Jenis penelitian yang digunakan dalam karya ilmiah ini adalah kualitatif, yaitu prosedur penelitian yang menghasilkan data deskriptif berupa kata-kata tertulis atau lisan dari orang-orang dan perilaku yang dapat diamati. Pendekatan ini diarahkan kepada latar individu secara utuh yang mana, dalam hal ini, tidak diperbolehkan mengisolasikan individu atau organisasi ke dalam variabel atau hipotesis, tetapi perlu memandangnya sebagai bagian dari ketuhanan.

Data yang digunakan dalam penelitian ini yaitu data yang diklasifikasikan dan dianalisis untuk mempermudah dalam menghadapkan pada pemecahan permasalahan, perolehannya dapat berasal dari yang pertama Informan penelitian. Informan dalam penelitian ini adalah data atau seorang yang memberikan informasi atau keterangan yang berkaitan dengan kebutuhan penelitian, informan yang dipilih peneliti yaitu, Kepala BAZDA, Petugas UPZ dan staf/karyawan, dokumen dan arsip. Dokumen merupakan bahan tertulis atau benda yang berhubungan dengan suatu peristiwa atau aktivitas tertentu. Dalam penelitian ini, yang dijadikan sumber data adalah dokumen-dokumen yang berhubungan dengan BAZDA Kabupaten Nganjuk. Dokumen tersebut yaitu tentang profil BAZDA Kabupaten N ganjuk, dokumen prestasi BAZDA K abupaten Nganjuk, program kerja BAZDA Kabupaten Nganjuk. Data yang digunakan dalam penelitian ini berdasarkan sumbernya dapat dibedakan menjadi dua. Pertama, data primer. Data primer merupakan sumber data penelitian yang diperoleh secara langsung dari sumber data asli (tidak melalui media perantara), ${ }^{14}$ meliputi pengamatan langsung dan dapat berupa opini subjek secara individual atau kelompok. Dalam penelitian ini, data primer berupa hasil wawancara dengan pengurus BA Z Kabupaten Nganjuk, pemerintah daerah dan para muzakki. K edua, data sekunder. Data sekunder merupakan data yang diperoleh peneliti secara tidak langsung melalui media perantara. Pada umumnya, data sekunder ini sebagai penunjang data primer. Data

\footnotetext{
${ }^{13}$ Robert S. Kaplan dan David P. Norton, The Balanced Scorecard ....., 26

${ }^{14}$ M. Iqbal Hasan, Pokok-Pokok Materi Metodologi Penelitian dan Aplikasinya (Jakarta: Ghalia Indonesia, 2002), 82
} 
sekunder diperoleh melalui laporan keuangan BAZDA Kabupaten Nganjuk dan juga dari buku-buku pustaka yang mendukung teori penelitian.

Pertama, data lapangan. Dalam hal ini, data lapangan diperoleh secara langsung pada objek penelitian. Dalam rangka mencari data yang akurat, penelitian ini penulis lakukan di BAZDA Kabupaten Nganjuk. A lat untuk mengumpulkan yaitu dengan wawancara, secara sistematis berdasarkan pada penyelidikan. K edua, dokumentasi. Dokumentasi adalah teknik pengumpulan data yang tidak langsung ditujukan pada subyek penelitian, namun melalui dokumen. Dokumen yang digunakan dapat berupa buku harian, surat pribadi, laporan, notulen rapat, catatan kasus dalam pekerjaan sosial dan dokumen lainnya. ${ }^{15}$ Dalam penelitian ini, dokumen yang dijadikan sebagai sumber dokumentasi adalah arsip resmi BAZDA Kabupaten Nganjuk mengenai data hasil penghimpunan dan pendayagunaan dana zakat, infaq dan shadaqah.

M etode analisis yang digunakan dalam dalam penelitian ini adalah deskriptif, yaitu metode penelitian yang dimaksudkan untuk menyelidiki keadaan, kondisi atau hal-hal lain yang sudah disebutkan dan hasilnya dipaparkan dalam bentuk laporan penelitian. ${ }^{16} \mathrm{M}$ etode ini digunakan untuk memberikan gambaran dan menganalisis secara sistematis terhadap beberapa fakta tentang situasi tertentu, pandangan, sikap dan kejadian terhadap hal-hal yang berhubungan dengan strategi peningkatan kinerja lembaga BAZDA Kabupaten Nganjuk, dengan mengguanakan metode analisis balanced scorecard dalam melakukan strategi peningkatan kinerja dengan didasarkapan pada empat presepektif yaitu perspektif keuangan, pelanggan, proses bisnis internal serta perspektif pembelajaran dan pertumbuhan.

Pengecekan keabsahan data diperlukan teknik pemeriksaan. Pelaksanaan teknik pemeriksaan didasarkan atas kriteria tertentu. Menurut Moleong, ada empat kriteria yang digunakan, yaitu derajat kepercayaan (credibility), ketrampilan (transferability), ketergantungan (dependability), dan kepastian (confirmability). ${ }^{17}$ Pada penelitian ini, teknik pemeriksaan yang digunakan adalah derajat kepercayaan (credibility), yaitu untuk membuktikan kesesuaian antara hasil pengamatan dengan kenyataan di lapangan. Untuk memperoleh kredibilitas data, peneliti mengacu kepada rekomendasi Lincoln dan Guba yang memberikan tujuh teknik untuk mencapai kredibilitas data yaitu pengamatan yang terus menerus, trianggulasi, membicarakan dengan rekan sejawat, menganalisis kasus negatif, menggunakan bahan refrensi, dan mengadakan member check.

\section{Hasil A nalisis D ata}

Berikut ini analisis mengenai strategi peningkatan kinerja BAZDA Kabupaten $\mathrm{N}$ ganjuk jika dilihat dari kacamata balanced scorecard yang terdiri dari empat perspektif.

Pertama, perspektif keuangan. Ini menyangkut tentang usaha BAZDA Kabupaten $\mathrm{Nganjuk}$ dalam meningkatkan penghimpunan dananya setiap saat. Beberapa upaya yang telah dilakukan BA ZDA Kabupaten N ganjuk dalam penghimpunan dana, antara lain:

\footnotetext{
${ }^{15}$ Ibid., 87

${ }^{16}$ Suharsini Arikunto, Prosedur Penelitian Suatu Pendekatan ....., 3

${ }^{17}$ Lexy. J. Moleong, Metode Penelitian Kualitatif ....., 173
} 
1) M embentuk UPZ (Unit Pengumpul Zakat)

Sesuai dengan Undang-Undang No. 23 tahun 2011 tentang pengelolaan zakat, BAZDA dapat membentuk UPZ di setiap instansi pemerintahan untuk membantu tugas dan fungsinya. Hal ini pula yang dilakukan BAZDA Kabupaten Nganjuk. BAZDA membentuk Unit Pengumpul Zakat (UPZ) di 20 kecamatan se K abupaten N ganjuk. Dan di instansi-intansi pemerintahan. Mengingat luasnya wilayah Nganjuk sendiri, maka dengan adanya UPZ ini akan sangat bermanfaat terutama dalam menunjang kinerja dari BAZDA K abupaten N ganjuk dalam hal funding.

2) M enyediakan rekening penyaluran zakat, infaq, dan shadaqah

BAZDA menyadari bahwa tidak semua masyarakat, khususnya muzakki memiliki waktu khusus untuk menyalurkan zakatnya melalui BAZDA. Oleh karena itu, untuk memudahkan muzakki dalam menyalurkan zakat, infaq, dan shadaqahnya, BAZDA K abupaten N ganjuk menyediakan rekening di berbagai bank, antara lain:

a) Rekening penyaluran zakat

a. Bank BRI dengan Nomor Rekening 0022-01-010793-50-4.

b. Bank BNI Syari' ah dengan N omor Rekening 0189101112

b) Rekening penyaluran shadaqah

a. Bank B NI Syari' ah dengan N omor Rekening 0164922701.

M elalui rekening ini, B AZDA K abupaten N ganjuk berharap akan semakin banyak masyarakat yang menyalurkan zakat, infaq dan, shadaqahnya. Dan ini tentunya akan berpengaruh signifikan terhadap tingkat penghimpunan dana oleh BAZDA Kabupaten Nganjuk. Dana ini untuk selanjutnya disalurkan kepada umat yang termasuk golongan mustahik.

3) Instansi Pemerintah (Untuk menjadikan PNS, BUMN dan BUMD sebagai sponsor penunaian zakat).

Di Instansi pemerintahan yang terjadi, pengumpulan ZIS di pegawai Pemerintah Daerah hampir sama dengan di Kecamatan. Namun berbeda ZIS yang ada di lingkungan Kementerian A gama sangat berbeda. Lebih sukses penghimpunan ZIS di lingkungan Kementerian Agama. Perolehan ZIS di Lingkungan Kementerian Agama meningkat secara siginifikan setelah adanya peraturan Menteri Agama tentang kewajiban membayar zakat setiap pegawai yag ada di lingkungan Kementrian Agama sebesar ketentuan dalam zakat profesi $2,5 \%$ dari total gaji yang diperoleh. Adapun data penghimpunan di lingkungan instansi pemerintah daerah dan kantor Kementerian A gama $\mathrm{K}$ abupaten $\mathrm{N}$ ganjuk sebagai berikut.

Tabel 1

Penghimpunan ZIS dilingkungan Instansi Pemerintahan dan Kankemenag Kabupaten N ganjuk T ahun 2014

\begin{tabular}{|c|l|r|}
\hline No & \multicolumn{1}{|c|}{ Instansi } & Zis Tahun 2014 \\
\hline 1 & Sekretariat Daerah & $14,334,500$ \\
\hline 2 & Sekretariat D prd & 840,000 \\
\hline
\end{tabular}




\begin{tabular}{|c|l|r|}
\hline 3 & B K D & $2,890,000$ \\
\hline 4 & Bappeda & $4,569,000$ \\
\hline 5 & Inspektorat & $2,525,000$ \\
\hline 6 & Lingkungan Hidup & $2,654,000$ \\
\hline 7 & D P 2 K A D & $8,014,000$ \\
\hline 8 & Bapemas Pemdes & $3,835,000$ \\
\hline 9 & Pu. Bina M arga & $5,313,000$ \\
\hline 10 & Sosnakertrans & $2,728,000$ \\
\hline 11 & Perhubungan & $9,464,000$ \\
\hline 12 & K ehutanan & $5,435,000$ \\
\hline 13 & Pertanian & $16,597,000$ \\
\hline 14 & Peternakan \& Perikanan & $8,750,000$ \\
\hline 15 & K esehatan & $5,715,800$ \\
\hline 16 & Pariwisata & $4,413,500$ \\
\hline 17 & D I K P 0 R A & $10,114,410$ \\
\hline 18 & Pu Cipta K arya & $10,341,500$ \\
\hline 19 & Pengairan & $6,268,000$ \\
\hline 20 & B P P K B D & $15,479,000$ \\
\hline 21 & Indagkoptamben & $3,252,000$ \\
\hline 22 & K esbangpollinmas & $1,550,000$ \\
\hline 23 & Pengadilan A gama & $1,710,000$ \\
\hline 24 & A R S I P & $1,656,000$ \\
\hline 25 & Perijinan & $3,755,000$ \\
\hline 26 & Satpol Pp & $2,056,000$ \\
\hline 27 & K ementerian A gama & $206,510,088$ \\
\hline 28 & K etahanan Pangan & $2,380,000$ \\
\hline 29 & Catatan Sipil & $4,267,000$ \\
\hline 30 & Baz K ab. N ganjuk & $4,065,000$ \\
\hline 31 & Rsud N ganjuk & $18,613,000$ \\
\hline 32 & Rsud K ertosono & $7,650,000$ \\
\hline 33 & Puskesmas Bagor & $8,090,000$ \\
\hline 34 & Puskesmas Nganjuk & $2,448,000$ \\
\hline 35 & Puskesmas Loceret & 2014 \\
\hline & $:$ Lam & \\
\hline
\end{tabular}

Sumber : Laporan Pertanggungjawaban BAZDA kabupaten Nganjuk 2014.

Jika dibandingkan dengan yang lain, instansi di lingkungan kementrian Agama dalam membayarkan ZISnya lebih banyak daripada instansi di bawah pemerintah daerah yang hanya membayar ZIS nya mengikuti petunjuk dan himbauan dari Bupati No.:451/365/411.501/2008 yang menghimbau kepada seluruh pegawai pemerintah daerah yang sudah memenuhi syarat wajib zakat hendaknya dipotong $2,5 \%$ dari gaji atau infaq / shdaqah yang besarnnya adalah untuk Golongan I Rp. 1000, Golongan II Rp. 
2.500, Golongan III Rp. 5.000, Golongan IV Rp. 10.000. Dengan berkembangnya waktu, peraturan tersebut masih belum bisa memaksimalkan kinerja BAZDA Kabupaten N ganjuk dalam menumbuhkan jiwa sosial yang tinggi di lingkuangan pemerintah daerah, hal ini dibuktikan pendapatan ZIS dari pejabat/ karyawan di lingkungan pemerintah daerah masih sangat minim sekali.

Seperti yang dibayarkan bukan zakatnya, namun hanya infaq yang sesuai himbauan Bupati. Hal ini kemudian pada tahun 2013 dihimbau kembali oleh Wakil Bupati dengan menerbitkan surat himbauan No.:451/240/411.012/2013 yang berisi tentang kepada seluruh pegawai pemerintah daerah yang sudah memenuhi syarat wajib zakat hendaknya dipotong $2,5 \%$ dari gaji atau infaq/shdaqah yang besarnnya adalah untuk Golongan I Rp. 3000, Golongan II Rp. 5.000, Golongan III Rp. 10.000, Golongan IV Rp. 20.000. Himbauan ini dilihat dari segi nominal infaq/shadaqah minimalnya meningkat 2 kali lipat dibandingkan himbauan surat dari bupati tahun 2008. Diharapkan dari surat himbau Bapak Wakil Bupati ini kesadaran berzakat dan berinfaq/ shdaqah dapat meningkat.

Dari berbagai upaya yang telah dilakukan BAZDA Kabupaten Nganjuk, dampaknya cukup signifikan. $\mathrm{Hal}$ ini bisa dilihat dari tabel di bawah ini:

Tabel 2

Penerimaan Zakat Infaq dan shodaqoh T ahun 2012-2014

\begin{tabular}{|l|c|r|c|}
\hline \multicolumn{1}{|c|}{ JENIS } & $\mathbf{2 0 1 2}$ & \multicolumn{1}{c|}{$\mathbf{2 0 1 3}$} & $\mathbf{2 0 1 4}$ \\
\hline Zakat M al & $34.110 .000,-$ & $69.315 .000,-$ & $558.435 .000,-$ \\
\hline Zaka Profesi & $360.316 .388,-$ & $536.476 .121,-$ & $580.963 .288,-$ \\
\hline $\begin{array}{l}\text { Infaq dan } \\
\text { shodaqoh }\end{array}$ & $386.124 .081,-$ & $371.585 .888,-$ & $675.054 .376,-$ \\
\hline J umlah & $780.550 .469,-$ & 977.377 .009 & $1.814 .452 .664,-$ \\
\hline
\end{tabular}

Dari sisi keuangan BAZDA Kabupaten Nganjuk Mulai periode 2013 sampai 2014, mengalami peningkatan sebesar 25,2\%. Dalam hal ini, penerimaan zakat profesi sangat meningkat secara baik dan Kementerian Agama Republik Indonesia juga menghimbau berdasarkan peraturan pemerintah Republik Indonesia Nomor 06 Tahun 2010 tentang zakat atau sumbangan keagamaan yang sifatnya wajib yang dapat dikurangi dari penghasilan bruto dengan ini seluruh pegawai yang di bawah Kementrian Agama, baik dari tingkat pusat, provinsi maupun kabupaten wajib membayarkan zakat profesi sebesar 2,5\% kepada Badan A mil Zakat setempat, sehingga peningkatan perolehan zakat profesi mencapai $81,7 \%$. Ini tentunya menjadi prestasi sekaligus menambah motivasi BAZDA Kabupaten $\mathrm{Nganjuk}$ dalam menjalankan setiap program kerjanya. Meskipun pertahunnya mengalami peningkatan yang signifikan, namun jika dibandingkan dengan potensi zakat di Nganjuk tahun 2012 yang mencapai Rp 20.515.554.925, hal ini tentunya masih jauh dari pencapaian yang maksimal.

M eningkatnya perolehan zakat, infaq dan shadaqah tentunya tidak terlepas dari peran muzakki sebagai pemilik harta. B erikut ini jumlah muzakki yang aktif pada setiap 
periodenya:

Tabel 3

Daftar muzakki aktif tahun 2012-2014

\begin{tabular}{|l|c|c|c|}
\hline \multirow{2}{*}{\multicolumn{1}{|c|}{ Sumber }} & \multicolumn{3}{c|}{ Jumlah M uzzaki yang A ktif } \\
\cline { 2 - 4 } & $\mathbf{2 0 1 2}$ & $\mathbf{2 0 1 3}$ & $\mathbf{2 0 1 4}$ \\
\hline $\begin{array}{l}\text { Intansi Pemerintah/ } \\
\text { BU M N/BU M D }\end{array}$ & 55 & 63 & 75 \\
\hline Lembaga Pendidikan & 54 & 57 & 60 \\
\hline Perorangan & 10 & 12 & 15 \\
\hline
\end{tabular}

Muzakki personal dan instansi pemerintahan/pendidikan lebih mendominasi dalam penunaian zakat, infaq dan shadaqah. Sementara itu, potensi pada unit perorangan masih belum cukup optimal. Terlebih lagi bidang industri/unit usaha swasta, yang sebenarnya memiliki potensi zakat sangat besar. Belum tersentuh sama sekali. Berikut ini sektor industri/unit usaha swasta yang diunggulkan di Kabupaten Nganjuk:

Tabel 4

Produk Domestic Regional Dan Potensi Zakat Kabupaten N ganjuk A tas Dasar Harga Konstan 2000 (Rp. Juta) ${ }^{18}$

\begin{tabular}{|c|c|c|c|c|}
\hline \multirow{3}{*}{ L apangan U saha } & \multicolumn{4}{|c|}{ Tahun } \\
\hline & \multicolumn{2}{|c|}{2013} & \multicolumn{2}{|c|}{2014} \\
\hline & PDRB & $\begin{array}{c}\text { Potensi } \\
\text { Zakat }\end{array}$ & PDRB & $\begin{array}{c}\text { Potensi } \\
\text { Zakat }\end{array}$ \\
\hline 1. Pertanian & 1.310 .265 & 32.757 & 1.361 .933 & 34.048 \\
\hline 2. Pertambangan & 64.659 & 1.616 & 66.676 & 1.667 \\
\hline 3. Industri & 344.319 & 8.608 & 359.589 & 8.990 \\
\hline 4. Listrik Gas \& Air B ersih & 16.493 & 412 & 17.505 & 438 \\
\hline 5. B angunan & 93.872 & 2.347 & 98.912 & 2.437 \\
\hline 6. Perdg. Htl\& Restoran & 1.447 .749 & 36.194 & 1.574 .265 & 39.357 \\
\hline 7. Pengangkutan\& Telkom & 86.907 & 2.173 & 92.412 & 2.310 \\
\hline 8. K eu.Sewa\& J asa Pers & 155.560 & 3.889 & 162.999 & 4.975 \\
\hline 9. Jasa-jasa & 393.397 & 9.835 & 418.308 & 10.458 \\
\hline T otal & 3.913 .021 & 97.837 & 4.152 .601 & 104.716 \\
\hline
\end{tabular}

Dari data di atas, potensi zakat di Kabupaten Nganjuk pada tahun 2013 mencapai sebesar Rp. 97,8 miliar dan pada tahun 2014 menjadi Rp 104,7 miliar karena adanya pertumbuhan PDRB sebesar $6.1 \%$ dari tahun 2013. Dari tabel 4.3 terlihat bahwa sektor ekonomi yaitu sektor perdadangan dan pertanian merupakan sektor yang memiliki potensi zakat yang terbesar di daerah ini, namum potensi zakat dari kedua sektor ini masih belum

\footnotetext{
${ }^{18}$ Firmansyah, "Potensi Peran Zakat Dalam Mengurangi Kemiskinan Studi Kasus Jawa Barat Dan Jawa Timur" (Pusat Penelitian Ekonomi LIPI 2009), 37
} 
disentuh oleh lembaga pengelola zakat, terutama oleh Badan A mil Zakat Daerah (BA ZDA) K abupaten N ganjuk.

Dari hasil perhitungan sederhana tentang perkiraan petensi zakat di atas, ternyata potensi zakat di Kabupaten Nganjuk cukup besar. Bila dibandingkan dengan Pendapatan A sli Daerahnya yaitu sebesar Rp. 53,2 miliar (BPS, 2014) maka besarnya potensi zakat hampir mencapai 2 kali dari PAD yang diperoleh Pemda setempat. Dengan kata lain, apabila potensi zakat tersebut dapat digali secara optimal, maka sumber baru dana pembangunan yang dapat digunakan untuk mengentaskan umat Islam dari kemiskinan cukup besar. Namun dilihat dari realisasi Zakat, Infaq dan Sedekah (ZIS) serta penerimaan lainnya yang mampu dikumpulkan oleh BAZDA K abupaten Nganjuk hanya mencapai Rp. 1.740.576.286 pada tahun 2014. Jika dibandingkan dengan perkiraan potensi zakat Kabupaten $\mathrm{N}$ ganjuk tahun 2014 yang R p.104,7 miliar maka rasio realisasi terhadap potensi masih sangat kecil yaitu 1,7\%.

Berdasarkan analisis pada perspektif keuangan, terdapat beberapa hal yang masih perlu ditingkatkan:

1) Potensi zakat profesi dari guru di lingkungan Kementerian A gama sangatlah maksimal namun hal ini belum terjadi di instansi pemerintah daerah. Jika hal ini dapat juga terjadi di pegawai daerah, maka pendapatan zakat profesi dapat meningkat dua kali lipat.

2) Potensi infaq dan shodaqoh setiap tahunnya selalu meningkat potensi ini bersumber dari seluruh pegawai di lingkungan pemerintah daerah dikarenakan surat dari bupati yang himbauan membayar zakat atau infaq/shadaqah namun dengan nominal yang sangat kecil, kemudian hal ini di sempurnakan lagi dengan surat himbauan dari wakil Bupati dengan nominal yang lebih besar sehingga pada tahun 2014 pendapatan dari infaq dan shadaqah meningkat. Namun, hal ini diharapkan dari pimpinan daerah dapat menerbitkan surat yang lebih tegas seperti kewajiban membayar zakat untuk pegawai di lingkungan Pemda. Tidak hanya sekedar himbauan. Seperti yang telah berlaku di lingkungan K ementrian A gama.

3) Untuk lebih mengoptimalkan penghimpunan dana inovasi baru lagi dalam menggali potensi zakat di kabupaten Nganjuk. Semisalnya mengadakan pecan peduli dan berbagi di lingkungan sekolah di seluruh kabupaten N ganjuk yang nanti dana akan diperuntukan untuk sosial.

Kedua, perspektif costomer atau pelanggan. Hal ini menyangkut sejauh mana usaha BAZDA Kabupaten Nganjuk dalam memberikan kualitas pelayanan yang terbaik kepada muzakki dan mustahik. Program pelayanan yang dimiliki BAZDA Kabupaten Nganjuk meliputi:

a) Sosialisasi

Tahun 2012 BAZDA Kabupaten Nganjuk untuk menunjukkan eksistensinya sebagai lembaga pengelola zakat, infaq dan shadaqah di Kabupaten $\mathrm{N}$ ganjuk. Di masamasa awal itu, BAZDA gencar melakukan sosialisasi tentang keberadaannya sebagai lembaga pengelola zakat, utamanya kepada instansi pemerintahan maupun pendidikan se Kabupaten Nganjuk. BAZDA juga mengadakan event lomba mengarang dengan bertemakan zakat untuk mendekatkan diri kepada para pelajar. BAZDA Kabupaten 
Nganjuk juga melakukan sosialisasi, baik melalui media cetak, seperti surat kabar, penyebaran pamflet, maupun media el ektronik seperti melalui radio Tasma $\mathrm{N}$ ganjuk.

BAZDA Kabupaten Nganjuk melakukan sosialisasi secara langsung dengan mendatangi daerah-daerah yang menurut pemantauan BAZDA masih minim tingkat kesadaran zakatnya, mendatangi majelis-majelis taklim, mendatangi perusahaanperusahaan di kabupaten Nganjuk dan juga berilaturrahmi khusus kepada aghniya' (muzakki ) potensial, maupun dengan meminta disediakan waktu di sela-sela pertemuan para pimpinan daerah guna mensosialisasikan tentang pentingnya peran zakat dalam perekonomian umat. Sosialisasi ini dilakukan secara continue agar kesadaran masyarakat akan pentingnya zakat tidak pupus terhapus oleh perjalanan waktu.

b) Jemput bola

A rtinya dari petugas BAZDA Kabupaten N ganjuk bersedia mengambil zakat ke rumah muzakki. Jadi, bagi muzakki yang sedang sibuk dan tidak memiliki waktu, dapat menghubungi BAZDA Kabupaten Nganjuk dan petugas akan langsung datang untuk menjemput zakat dari muzakki. Y ang sudah berjalan selama ini, BAZDA menjemput bola zakat dari dinas instansi dan juga para muzakki serta para aghniya' besar potensial. Sementara muzakki personal sebagian besar menyalurkan zakatnya melalui rekening maupun dengan datang langsung ke kantor BA ZDA K abupaten N ganjuk.

c) Konsultasi dan penghitungan zakat

Jika muzakki belum mengerti tentang nominal zakat yang mesti dikeluarkan, bisa menghubungi petugas ataupun datang langsung ke kantor BAZDA Kabupaten N ganjuk. Petugas akan membantu mendata seluruh harta kekayaan dari pihak muzakki, selanjutnya dilakukan penghitungan besarnya zakat yang seharusnya dikeluarkan. $M$ ayoritas muzakki sebelum memberikan zakat, infaq maupun shadaqahnya, mendatangi kantor BAZDA Kabupaten Nganjuk terlebih dahulu guna berkonsultasi dan minta dihitungkan zakat yang harus dikeluarkannya. Setelah itu muzakki dapat menyalurkan zakat, infaq dan shadaqahnya baik melalui rekening maupun dibayarkan langsung di kantor BAZDA Kabupaten N ganjuk.

Masih menyangkut dengan kualitas pelayanan, BAZDA Kabupaten Nganjuk dalam merekrut pegawai yang mengutamakan pada kompetensi yang dimiliki. Karena selain kejujuran, kemampuan staff/pegawai dalam hal pemahaman zakat serta penerapannya dalam manajemen sangat urgent, terutama pada hal-hal yang berhubungan dengan pencatatan/pengadministrasian. Dalam rangka menunjang hal itu, BAZDA Kabupaten Nganjuk secara khusus mendelegasikan 2 orang staff/pegawainya untuk mengikuti pendidikan akuntansi yang diadakan oleh BAZDA pusat. Hal ini sangat penting karena pelaporan keuangan yang dibuat harus menyesuaikan dengan pedoman akuntansi yang berlaku, karena setiap saat BAZDA harus siap diaudit oleh akuntan publik.

Selain itu, BAZDA Kabupaten Nganjuk tentunya membutuhkan sarana prasarana yang dapat menunjang proses pelayanan optimal. K etika dilakukan wawancara dengan Ahmad, S.Sos, menyatakan bahwa BAZDA Kabupaten Nganjuk selalu memperhatikan sarana prasarana dengan menyediakan segala keperluan yang 
dibutuhkan, seperti komputer, peralatan kantor, kendaraan dinas dan lain sebagainya. Dengan adanya sarana prasarana tersebut, diharapkan mampu memaksimalkan pelayanan yang dilakukan oleh staff/pegawai kepada muzakki.

BAZDA Kabupaten Nganjuk melakukan koordinasi dengan UPZ se Kabupaten Nganjuk guna lebih memacu kinerja masing-masing UPZ. Pada tahun 2014 BAZDA juga mengadakan pelatihan kepada UPZ desa/kelurahan dan kecamatan se Kabupaten Nganjuk dalam bentuk workshop dengan jumlah peserta kurang lebih 500 orang. U paya-upaya ini merupakan bentuk apresiasi dan juga tanggung jawab BAZDA untuk semakin memberdayakan sumber daya manusia yang dimilikinya sehingga kualitas pelayanan yang diberikan sesuai dengan harapan.

BAZDA Kabupaten Nganjuk juga membuat laporan tentang kinerjanya dalam setiap periode, serta mempertanggungjawabkan kepada Bupati, DPRD, BAZDA Provinsi, BAZDA Pusat serta menyampaikan buku laporan kepada para muzakki. Hal ini dilakukan untuk menjaga kepercayaan dari para muzakki dan tentunya sesuai dengan aturan U ndang-U ndang Nomor 23 tahun 2011 tentang pengelolaan zakat pasal 29.

Berdasarkan perspektif costumer, ada hal yang hendaknya mendapatkan perhatian BAZDA Kabupaten Nganjuk:

1) Mengenai sosialisasi zakat oleh BAZDA Kabupaten Nganjuk, hendaknya lebih ditingkatkan lagi. Hal ini karena jika dihubungkan dengan adanya sumber-sumber dana potensial yang belum terserap optimal dan potensi zakat yang ada di Kabupaten Nganjuk, tentunya penghimpunan dana yang signifikan selama ini, belum bisa dikatakan optimal.

2) Kepercayaan muzakki yang merupakan salah satu kunci keberhasilan BAZDA, hendaknya selalu dijaga. Dengan kepercayaan tersebut, tentunya semakin banyak muzakki yang lebih memilih menyalurkan zakatnya melalui BAZDA Kabupaten Nganjuk.

Ketiga, perspektif bisnis internal. Perspektif proses bisnis internal merupakan usaha BAZDA untuk mengentaskan kemiskinan secara adil dan tepat, melalui pendayagunaan serta pemberdayaan terhadap hal-hal yang seharusnya diunggulkan. Berikut ini besaran alokasi pendayagunaan dan pemberdayaan zakat BAZDA K abupaten $\mathrm{N}$ ganjuk :

Tabel 5

Perolehan, alokasi pendayagunaan serta pemberdayaan dana

Oleh BAZDA K abupaten N ganjuk

\begin{tabular}{|l|r|r|r|}
\hline Tahun & \multicolumn{1}{|c|}{ Perolehan } & \multicolumn{1}{c|}{$\begin{array}{c}\text { A lokasi } \\
\text { pendayagunaan }\end{array}$} & \multicolumn{1}{c|}{$\begin{array}{c}\text { Alokasi } \\
\text { pemberdayaan }\end{array}$} \\
\hline $\mathbf{2 0 1 2}$ & $780.550 .469,-$ & $580.411 .194,-$ & $9.150 .000,-$ \\
\hline $\mathbf{2 0 1 3}$ & $977.377 .009,-$ & $993.620 .280,-$ & $30.350 .000,-$ \\
\hline $\mathbf{2 0 1 4}$ & $1.814 .452 .664,-$ & $1.598 .718 .088,-$ & $39.263 .000,-$ \\
\hline
\end{tabular}

Sumber: L aporan K euangan B A ZD A K abupaten N ganjuk

Dari tahun 2012 BAZDA Kabupaten Nganjuk masih memiliki uang kas pada tahun 2011 senilai Rp. 308.279.647,76 dan pemasukan pada tahun 2012 sebesar Rp. 780.550.469, 
sehingga total pemasukan Rp. 1.088.830.116,8 dialokasikan pada tahun 2012 sebesar Rp. 589.561,19 pada tahun 2013 BAZDA Kabupaten Nganjuk memiliki kas Rp. 499.268.992,8 dan menerima pemasukan pada tahun 2013 sebesar Rp. 977.377.009. Total pemasukan Rp. 1.476.646.001,8 alokasi pada tahun 2013 ini lebih besar dari pada pendapatan yaitu Rp. 993.620.280. Namun BAZDA Kabupaten Nganjuk karena masih memiliki kas dari tahun 2012, sehingga BAZDA Kabupaten Nganjuk masih memiliki sisa dana sebesar Rp. 483.025.721.8. Di tahun 2014 pendapat BAZDA Kabupaten Nganjuk meningkat mencapai $82 \%$ sehingga total pemasukan Rp. 2.297.478.358 dan alokasi untuk tahun 2014 sebesar Rp. 1.637.981.088 sisa kas pada tahun 2014 R p. 669.497.270.

A lokasi pendayagunaan di atas, diberikan kepada golongan yang kurang mampu guna membantu meringankan beban mereka dalam memenuhi kebutuhan pokoknya (konsumtif). Sedangkan alokasi pemberdayaan, digunakan untuk membentuk kelompok usaha pada tahun 2014 masih sangat kecil yaitu 39.263.000,-. yang digunakan sebagai bantuan modal usaha mustahiq. Jenis usaha para M ustahiq diberdayakan dalam bentuk pelatihan memasak kemudian diberikan bantuan modal. Sampai saat ini, perkembangannya masih dalam tahap pembinaan dan pengawasan oleh BA ZDA K abupaten N ganjuk.

Bertambahnya penghimpunan dan pendistribusian zakat ternyata belum berbanding lurus dengan penurunan jumlah penduduk miskin. Badan Pusat Statistik Nganjuk menyatakan bahwa jumlah penduduk miskin setiap tahunnya meningkat. Hal ini nampaknya juga dipengaruhi seiring bertambahnya jumlah penduduk serta realisasi pemberdayaan zakat yang belum optimal. Berikut ini tabel keadaan penduduk di Kabupaten Nganjuk tiga tahun terakhir:

Tabel 6

Pertumbuhan penduduk

Dan jumlah penduduk miskin di Kabupaten $\mathrm{N}$ ganjuk

\begin{tabular}{|c|l|l|}
\hline Tahun & $\begin{array}{c}\text { Pertumbuhan } \\
\text { Penduduk }\end{array}$ & $\begin{array}{c}\text { Jumlah Penduduk } \\
\text { M iskin }\end{array}$ \\
\hline $\mathbf{2 0 1 2}$ & 1.043 .503 Jiwa & 104.744 Jiwa \\
\hline $\mathbf{2 0 1 3}$ & 1.063 .555 Jiwa & 111.564 Jiwa \\
\hline $\mathbf{2 0 1 4}$ & 1.069 .299 Jiwa & 405.005 Jiwa \\
\hline
\end{tabular}

Sumber: L aporan B PS K abupaten N ganjuk

Jika melihat pada tabel sebelumnya, alokasi pendayagunaan zakat secara konsumtif jauh lebih besar dibandingkan dengan model pemberdayaan zakat secara produktif. Padahal dengan pemberdayaan zakat secara produktif, dapat melatih sifat kemandirian serta ketrampilan dari mustahik, serta adanya harapan besar untuk merubah status mustahik menjadi muzakki. Mengenai hal ini, pengurus BAZDA Kabupaten Nganjuk menyatakan bahwa mulai tahun 2011, BAZDA sudah melakukan pemberdayaan zakat produktif berupa pemberian modal usaha bagi mustahik, meskipun alokasinya belum maksimal. Hal ini karena BAZDA melihat perkembangan keadaan penduduk miskin di Kabupaten Nganjuk sendiri cenderung bertambah, sehingga perhatian utama masih difokuskan pada pendayagunaan zakat konsumtif untuk membantu mereka dalam memenuhi kebutuhan 
pokoknya.

Mengenai wilayah yang menjadi prioritas BAZDA Kabupaten Nganjuk dalam pendistribusian zakat meliputi Desa Kec. Pace, Kec. Sawahan, Kec. Berbek, Kec. Gondang, $\mathrm{Kec}$. Rejoso, Kec. Ngeluyu, Kec. Jati Kalen, Kec. Rejoso, Kec. Wilangan. Wilayah ini menurut pemantauan Pemkab N ganjuk tergolong daerah yang masyarakatnya perlu dibantu.

Perlu disyukuri juga bahwa pengelolaan zakat oleh BAZDA Kabupaten Nganjuk mendapatkan dukungan dari berbagai pihak, baik dari muzakki maupun dari pihak birokrasi sendiri. M uzakki indikatornya adalah meningkatnya masyarakat yang menyalurkan zakat, infaq dan shadaqah melalui BAZDA Kabupaten Nganjuk. Sedangkan dari pihak birokrat, yaitu Bupati N ganjuk menempati jajaran dewan pertimbangan BAZDA serta adanya dana alokasi khusus untuk membantu biaya operasional BAZDA Kabupaten Nganjuk setiap tahunnya. Berikut ini tabel mengenai besaran dana bantuan untuk operasional BAZDA Kabupaten $\mathrm{N}$ ganjuk:

Tabel 7

B antuan operasional dari Pemkab Nganjuk

\begin{tabular}{|c|c|}
\hline Tahun & Bantuan Operasional \\
\hline 2012 & Rp 150.000.000 \\
\hline 2013 & Rp 150.000.000 \\
\hline 2014 & - \\
\hline
\end{tabular}

Sumber: Laporan K euangan B A ZD A K abupaten N ganjuk

Dana bantuan ini dirasakan sangat urgen karena nantinya digunakan untuk membantu operasional, baik bagi BAZDA Kabupaten Nganjuk maupun bagi UPZ kecamatan. Jika hanya mengandalkan dana dari perolehan zakat, infaq dan shadaqah, dikhawatirkan dana yang seharusnya diberikan kepada mustahik habis untuk biaya operasional BAZNAS. Namun untuk tahun anggaran 2014 terkendala dengan adanya penghapusan bantuan hibah sehingga BAZDA Kab. Nganjuk tidak menerima dana hibah tersebut. Kemudian untuk tahun depan akan memperoleh kembali dengan pengalokasian operasional daerah yang dimasukkan ke anggaran APBD Daerah Kab. Nganjuk hal itu yang disampaikan oleh Bupati Kab. Nganjuk.

B erdasarkan analisis pada perspektif proses bisnis/intern, terdapat beberapa hal yang perlu ditingkatkan:

a. Realisasi pemberdayaan zakat produktif nampaknya perlu dioptimalkan. Dengan pendayagunaan secara konsumtif saja, belum cukup untuk membantu mustahik terlepas dari belenggu kemiskinan. Perlu adanya upaya untuk melatih kemandirian dan juga ketrampilan mustahik. Diharapkan dengan pelatihan tersebut, akan berpengaruh terhadap pola pemanfaatan dana zakat yang diberikan. Sehingga kelak dengan ketrampilan yang dimiliki, dapat menghasilkan nilai ekonomis bagi mustahik.

b. M engenai upaya pemberian modal usaha bagi mustahik, BAZDA Kabupaten N ganjuk dibantu UPZ K ecamatan harus selalu bersinergi melakukan pembinaan dan pengawasan terhadap pemanfaatannya. Hal ini agar diketahui mengenai pemanfaatan dana serta perkembangan dari usaha mustahik. Sehingga jika ada usaha yang potensial, BA ZDA 
dapat membantu dalam proses pengembangannya. Dari sini juga, bisa menjadi media pembelajaran bagi BAZDA K abupaten $\mathrm{N}$ ganjuk dalam pemberdayaan zakat produkif.

\section{Perspektif Pertumbuhan dan Pembelajaran}

Perspektif pertumbuhan dan pembelajaran menyangkut bagaimana BAZDA menjamin kemampuannya untuk berubah, berkembang, dan bermanfaat.

Profesionalisme lembaga erat kaitannya dengan skill dari sumber daya manusia yang dimiliki sebuah lembaga. BAZDA K abupaten N ganjuk sangat memperhatikan kualitas dari sumber daya manusianya dalam hal ini adalah staff/pegawainya. BAZDA setiap saat selalu melakukan pembinaan yang dilakukan secara langsung oleh ketua badan pelaksana A hmad, S. Sos, berupa arahan dan motivasi. A da juga bentuk pembinaan yang dilakukan secara tidak langsung, misalnya melalui kegiatan studi banding, sosialisasi ke daerah-daerah maupun berbagai instansi, proses pelayanan kepada masyarakat dan lain sebagainya. BAZDA K abupaten N ganjuk juga secara khusus mendelegasikan 2 orang staff kantor untuk mengikuti pendidikan akuntansi yang diadakan oleh BAZDA pusat. T ujuan utamanya adalah untuk meningkatkan kualitas dalam hal pengadministrasian dan diharapkan ilmu yang telah diperoleh dari pendidikan tersebut bisa diajarkan kepada staff kantor yang lainnya.

BAZDA Kabupaten Nganjuk sendiri juga mengadakan pelatihan pada tahun 2013 dalam bentuk workshop kepada UPZ instansi maupun kecamatan seK abupaten N ganjuk guna meningkatkan profesionalisme mereka, terutama dalam memberikan pelayanan terhadap masyarakat. Pada tahun 2014 B AZDA Kabupaten N ganjuk mengadakan kunjungan pada BAZDA di daerah lain, yaitu di BAZDA Kabupaten Tulungagung. Diadakannya kunjungan ini adalah untuk saling share mengenai program kerja masing-masing lembaga dan juga berbagi pengalaman yang nantinya bisa digunakan sebagai salah satu referensi untuk penyusunan program kerja ke depannya.

Selain mengadakan kunjungan, BAZDA Kabupaten Nganjuk juga mengadakan pelatihan wirausaha kepada mustahiq yang masih kuat untuk bekerja agar mampu meningkatkan pendapatan ekonominya. Dan kemudian setelah diadakannya pelatihan kewirausahaan diberikan bantuan modal untuk memulai usaha dengan kisaran 5 juta sampai 10 juta. Program ini sangat efektif sekali untuk membantu mustahik dalam memiliki pekerjaan. Berbagai upaya telah dilakukan BAZDA untuk menuju perkembangan yang lebih baik lagi. Setiap bulannya diadakan rapat pengurus guna memantau dan juga evaluasi terhadap pencapaian kinerja selama periode tersebut. BAZDA juga mengadakan koordinasi dengan UPZ se K abupaten N ganjuk dalam kurun waktu tertentu.

Berdasarkan perspektif pertumbuhan dan pembelajaran, terdapat beberapa hal yang perlu mendapatkan perhatian BAZDA Kabupaten Nganjuk, yaitu menyiapkan suatu kebijakan berkenaan dengan proses pembelajaran sekaligus mencapai pertumbuhan lembaga yang optimal, BAZDA Kabupaten Nganjuk tentunya membutuhkan sumber referensi baik dari internal maupun eksternal lembaga. Internal dapat berupa laporan kinerja lembaga setiap periodenya, sedangkan eksternal berupa masukan-masukan dari muzakki maupun mustahik. Oleh karena itu, perlu disediakan suatu media sebagai alternatif masyarakat dalam menyalurkan aspirasinya kepada BAZDA Kabupaten Nganjuk. Karena dengan aspirasi 
tersebut, secara tidak langsung masyarakat dilibatkan dan ikut bertanggungjawab terhadap pengelolaan zakat, infaq dan shadaqah di Kabupaten N ganjuk.

Dalam rangka memberikan kepercayaan muzakki terhadap lembaga amil zakat, diperlukan kualitas manajemen lembaga amil zakat dan sifat amanah para pengelolanya. U paya menghindari ketidaktepatan dalam mengumpulkan dan menyalurkan dana zakat, perlu dilakukan manajemen zakat. Dengan demikian, diharapkan dapat memberdayakan zakat sebagai sarana untuk mewujudkan tujuan sosial, mengembangkan masyarakat dan menyelamatkan modal harta dan pengembangannya. Konsekuensinya akan menimbulkan kepercayaan para mustahik zakat melalui lembaga pengelola zakat.

Untuk itu, BAZDA Kabupaten Nganjuk menyediakan kader-kader yang berkemampuan luas. Karena pengelolaan zakat secara profesional memerlukan tenaga yang terampil, menguasai masalah-masalah yang berkaitan dengan zakat, seperti nisab, haul, muzakki dan mustahik zakat. Selaku tenaga operasional BAZDA berinisiatif mengumpulkan zakat dari para wajib zakat secara langsung. Para tenaga operasional itu secara door to door datang kepada wajib pajak zakat di rumah mereka. Dalam hal ini, para wajib zakat tidak begitu saja dipungut zakatnya. Pada mulanya, wajib zakat diberi surat pemberitahuan yang isinya menyatakan bahwa BAZDA siap memungut dan mengelola zakat mereka.

Mengenai mekanisme penyaluran dana zakat, infaq dan shadaqah, BAZDA tidak melaksanakan pada delapan asnaf saja, karena menurut BAZDA Kabupaten Nganjuk tidak semua asnaf itu ada pada saat ini. Golongan riqab, gharimin dan muallaf masing-masing sulit didapatkan pada kondisi sekarang.

Dalam menentukan pihak yang akan mendapatkan bagian zakat diadakan musyawarah semua pengurus BAZDA. Y ang demikian ini sangat diperlukan karena terlalu banyak calon mustahik yang diusulkan. Model pendayagunaan zakat, infaq dan shadaqah BAZDA Kabupaten N ganjuk meliputi beberapa model. Pertama, konsumtif tradisional, yaitu zakat digunakan dan dimanfaatkan langsung oleh mustahik, seperti zakat fitrah yang langsung diberikan kepada fakir miskin untuk memenuhi kebutuhan sehari-hari atau harta yang disumbangkan untuk bencana alam. Kedua, konsumtif kreatif, yaitu zakat yang diwujudkan dalam bentuk lain dari barangnya semula, seperti diwujudkan dalam bentuk alat-alat sekolah dan beasiswa. Ketiga, produktif tradisional, yaitu zakat yang diberikan dalam bentuk produktif, seperti kambing, sapi, mesin jahit dan sebagainya. Keempat, produktif kreatif, yaitu pendayagunaan zakat diwujudkan dalam bentuk modal baik untuk pembangunan proyek sosial maupun menambah modal seorang pedagang atau pengusaha kecil. Untuk memudahkan muzakki dalam menyalurkan zakatnya, BAZDA Kabupaten Nganjuk menyediakan layanan seperti, jemput bola, konsultasi zakat dan penghitungan zakat.

Selain dari penghimpunan, pendayagunaan, fungsional (sumber daya manusia) dan pelayanan yang maksimal, BAZDA Kabupaten Nganjuk juga melakukan pelaporan secara berkala kepada muzakki. Hal ini dilakukan selain untuk menunjukkan keprofesionalan BAZDA Kabupaten Nganjuk, juga untuk menjaga dan semakin menambah kepercayaan masyarakat khususnya muzakki seiring dengan usaha BAZDA Kabupaten Nganjuk 
meningkatkan kualitas manajemennya sebagai lembaga pengelola zakat, infaq dan shadaqah.

\section{Kesimpulan}

Berdasarkan hasil penelitian mengenai strategi peningkatan kinerja BAZDA K abupaten $\mathrm{N}$ ganjuk, ada beberapa hal yang perlu diperhatikan:

1. Berdasarkan perspektif keuangan, masih terdapat beberapa bidang yang sebenarnya potensial, namun belum bisa terserap secara optimal.

2. Berdasarkan perspektif proses bisnis/intern, realisasi pendayagunaan zakat konsumtif lebih besar dibandingkan dengan pemberdayaan zakat secara produktif.

3. Berdasarkan perspektif costumer, ketika proses sosialisasi zakat dihubungkan dengan hasil penghimpunan dana, serta masih adanya beberapa bidang potensi zakat yang belum tergali secara maksimal, maka upaya sosialisasi masih memerlukan usaha yang lebih proaktif lagi.

4. Berdasarkan pertumbuhan dan pembelajaran, untuk kemajuan lembaga BAZDA Kabupaten Nganjuk membutuhkan sumber referensi baik internal maupun eksternal lembaga. Internal lembaga dapat berupa laporan kinerja lembaga setiap periodenya, sedangkan eksternal berupa masukan-masukan dari muzakki maupun mustahik.

\section{Daftar R ujukan}

A rikunto, Suharsimi, Prosedur Penelitian Suatu Pendekatan Praktik, Jakarta: Rineka Cipta, 2010

Daud, A li M uhammad, Lembaga lembaga Islam di Indonesia, Jakarta: Gravindo Persada, 1995

Firmansyah, "Potensi Peran Zakat Dalam Mengurangi Kemiskinan Studi Kasus Jawa Barat

Dan Jawa Timur", Pusat Penelitian Ekonomi LIPI 2009

Kaplan, Robert S., dan David P. N orton, Balanced Scorecard: M enerapkan Strategi M enjadi A ksi, J Jakarta: E rlangga, 2000

Modell, Sven, "Performance M easurement M yths in Public Sector", dalam www.ssrn.com diakses tanggal 12 Februari 2015

Moleong, Lexy J., M etode Penelitian Kualitatif, B andung: PT Remaja Rosdakarya, 2004 M ulyadi, B alanced Scorecard : A lat M anajemen Kontemporer untuk Pelipatgandaan K inerja Keuangan Perusahaan, J akarta: Salemba Empat, 2001

M ursyidi, A kuntansi Zakat Kontemporer, Bandung: Remaja Rosdakarya, 2006

Nany, Magdalena, Lyna Raharjo, Kartika Winda Handini, "Penerapan Balanced Scorecard Sebagai Pengukur Kinerja Manajemen pada RSUD Indramayu", dalam Jurnal Riset A kuntansi dan Keuangan, Vol. 4, No.1, Februari 2008

Salim, Challenging the secular state The Islamic of Law in Modern Indonesia, Honolula: University of Hawai Press, 2008

Suharsimi, A rikunto, Prosedur Penelitian: Suatu Pendekatan Praktek, Jakarta: PT. Rineka Cipta, 2002

Tandiontong, Mathius dan Verani Carolina, "Pengaruh Efektivitas Penerapan Metode 
B alanced Scorecard dalam M eningkatkan Kinerja Perusahaan: Studi Kasus pada PT PLN Persero Distribusi Jabar dan Banten", dalam Jurnal Riset A kuntansi, Vol.III No.2 (Oktober 2011)

Tika, M oh. Pabundu, B udaya Organisasi dan Peningkatan Kinerja Perusahaan, J akarta: Sinar Grafika Offset, 2006

Ulum, I hyaul M .D., A udit Sektor Publik Suatu Pengantar, J akarta: B umi A ksara, 2006 